\title{
Mempertanyakan Pengelolaan Publicness Pada Kawasan Malioboro-Ahmad Yani Ditengah Dominasi Perekonomian
}

\section{Questioning The Management of Publicness In Malioboro-Ahmad Yani Area In The Middle of Economic Dominance}

\author{
Fadlurrahman $^{1}$, Seiren Ikhtiara ${ }^{2}$, Nike Mutiara Fauziah ${ }^{1}$, Amaliatulwalidain $^{3}$ \\ ${ }^{1}$ Program Studi Ilmu Administrasi Negara Fakultas Ilmu Sosial dan Ilmu Politik Universitas \\ Tidar \\ ${ }^{2}$ Program Studi Ilmu Komunikasi Fakultas Ilmu Sosial dan Ilmu Politik \\ Universitas Widya Mataram \\ ${ }^{3}$ Program Studi Pemerintahan Fakultas Ilmu Pemerintahan dan Budaya \\ Universitas Indo Global Mandiri \\ Fadlurrahman@untidar.ac.id
}

\begin{abstract}
Abstrak
Penelitian ini bertujuan untuk mendeskripsikan pengelolaan publicness yang dilakukan oleh pemerintah Kota Yogyakarta melalui UPT Malioboro. Dengan metode kualitatif dan pendekatan studi kasus, ditemukan bahwa: (1) Pengelolaan publicness mengalami tekanan yang kuat dari pasar; (2) Eksistensi publicness dikelola dengan cara negosiasi kepentingan; (3) Otoritas pemerintah turut melemahkan derajat publicness ketika adanya tekanan dari kelompok ekonomi; (4) Publicness tereduksi ketika minimnya peran dan kontrol pemerintah; dan (5) Derajat publicness meningkat pasca adanya relokasi parkir kendaraan. Saran yang ditawarkan yaitu pemerintah perlu memperkuat komitmen untuk mengelola kawasan Malioboro-Ahmad Yani yang berorientasi pada kepentingan publik. Selain itu pemerintah perlu memprediksi perkembangan kelompok-kelompok ekonomi dan menciptakan sistem antisipasi/solusi tanpa melemahkan publicness.
\end{abstract}

\section{Kata kunci : Publicness, kelompok ekonomi, Malioboro}

\begin{abstract}
This study aims to describe the management of publicness by the government of Yogyakarta through UPT Malioboro. With qualitative method and case study approach, the result of research showed that: (1) The management of publicness is experiencing strong pressure from the market; (2) The existence of publicness is managed with the negotiation of interests; (3) The government authorities participated weaken the degree of publicness when the government gets pressure from economic groups; (4) Publicness is reduced when the lack of government's role and control; and (5) The degrees of publicness value increasing post-war presence of the relocation of the vahicles parking. This study suggested the government needs to strengthen its commitment to manage the Malioboro-Ahmad Yani area that is oriented to the public orientation. In addition the government need to predict the progression of economic groups and create an anticipation system/solution without weakening the publicness.
\end{abstract}

Keywords : Publicness, economic groups, Malioboro 


\section{A. Pendahuluan}

Adanya kegiatan perekonomian suatu kelompok di suatu kawasan merupakan hal yang baik sebagai pertanda munculnya usaha untuk menyejahterakan kehidupan. Namun, bagaimana bila kegiatan perekonomian tersebut berada pada kawasan yang pada awal pembentukannya diperuntukkan khusus untuk publik tanpa adanya kegiatan perekonomian, hingga tempat publik tersebut bertransformasi menjadi pusat bisnis yang mana memiliki kompleksitas isu dan konflik berbagai nilai yang terkandung di dalamnya. Salah satu kawasan yang digambarkan secara ringkas tersebut yakni Kawasan Malioboro-Ahmad Yani di Kota Yogyakarta.

Kawasan Malioboro-Ahmad Yani merupakan suatu tempat publik yang dikelola oleh Unit Pelaksana Teknis (UPT) Malioboro di bawah naungan Dinas Pariwisata dan Kebudayaan Kota Yogyakarta melalui Peraturan Wali Kota Yogyakarta No. 92 Tahun 2009 tentang pembentukan, susunan, kedudukan, fungsi dan rincian tugas unit pelaksanaan teknis pengelolaan kawasan Malioboro Pada Dinas Pariwisata dan Kebudayaan Kota Yogyakarta. UPT Malioboro sendiri merupakan unit gabungan yang khusus dibentuk dari beberapa instansi pemerintahan, yakni dinas kiraswil, perindustrian, perdagangan, koperasi dan pertanian, perhubungan, badan lingkungan hidup, ketertiban, serta dinas pariwisata dan kebudayaan.

$\begin{array}{lcr}\text { Berdasarkan } & \text { Perwalkot } & \text { Yogyakarta } \\ \text { tersebut, } & \text { maka } & \text { tugas }\end{array}$ mengimplementasikan berbagai kebijakan pemerintah dalam rangka penataan dan pengelolaan kawasan Malioboro-Ahmad Yani berada pada kekuasaan dan tanggung jawab UPT Malioboro. Meskipun UPT Malioboro satu-satunya organisasi formal yang ditunjuk secara resmi mengelola kawasan Malioboro-Ahmad Yani, namun pada kenyataannya terdapat kekuatan (organisasi) informal yang turut memainkan peran sebagai pengelola kawasan Malioboro-Ahmad Yani. Adanya kenyataan bahwa terdapat aktor lain selain UPT Malioboro, hal tersebut disebabkan karena adanya kepentingan-kepentingan tersendiri yang dibawa oleh organisasi informal tersebut.

Kawasan Malioboro-Ahmad Yani yang seharusnya menjadi domain wilayah pengelolaan pemerintah, telah bergeser menjadi ranah privat dan ekonomi/bisnis yang bukan hanya dikelola oleh pemerintah sendiri, melainkan turut dikelola oleh berbagai macam organisasi informal lain yang mempunyai kepentingan dibalik pengelolaan yang dilakukan. Riset terdahulu menyebutkan bahwa pengelolaan kawasan MalioboroAhmad Yani di dominasi oleh organisasi informal atau yang disebut sebagai kelompok perekonomian (paguyuban) yang mana memiliki power lebih besar dibanding negara (Cahyadi et., al., 2011: 19). Ketika pengelolaan kawasan Malioboro-Ahmad Yani di dominasi oleh kelompok perekonomian, dikhawatirkan orientasi bisnis akan menajam dan berpeluang mereduksi publicness.

Keberadaan berbagai kelompok perekonomian di kawasan MalioboroAhmad Yani diperkirakan mencapai puluhan kelompok dan terus berkembang 
(Putri, 2015). Satu hal yang pasti yakni kawasan Malioboro-Ahmad Yani tidak dapat terpisahkan dari keberadaan kelompok ekonomi dan hal tersebut mengukuhkan bahwasanya terdapat hegemoni perekonomian dengan kepentingan yang besar, yakni kepentingan pasar. Dinamika pada kawasan MalioboroAhmad Yani melahirkan isu yang kompleks terkait eksistensi kelompok ekonomi dan ketersediaan akses publik terhadap fasilitas di kawasan MalioboroAhmad Yani. Hegemoni kelompok perekonomian yang direalisasikan melalui dominasi kegiatan perekonomian diberbagai sudut kawasan MalioboroAhmad Yani akhirnya meminggirkan kepentingan publik dalam mengakses fasilitas yang ada, misalnya jalur pedestrian.

Pemerintah memiliki tanggung jawab melindungi dan mengelola kepentingan publik ditengah keadaan bahwasanya kepentingan publik semakin terancam oleh hegemoni perekonomian. Oleh sebab itu, pengelolaan dan kontrol pada kawasan Malioboro-Ahmad Yani sepatutnya dilakukan oleh pemerintah itu sendiri agar kepentingan publik dapat terlindungi. Namun, kenyataan besar yang tengah terjadi yaitu pengelolaan kawasan Malioboro-Ahmad Yani tidak semata-mata dilakukan oleh pemerintah saja, tetapi tata kelola tersebut juga dilakukan oleh kelompok perekonomian yang menjadikan kawasan Malioboro-Ahmad Yani sebagai kanal perekonomiannya. Ketika suatu organisasi informal masyarakat (apapun bentuknya) menjadi aktor pengelola tempat publik, maka hal tersebut akan berdampak paralel pada setiap aspek, terkhusus pada kepentingan publik.
Isu dalam pengelolaan kawasan Malioboro-Ahmad Yani jelas merupakan isu publicness. Kawasan MalioboroAhmad Yani menjelma menjadi arena kontestasi nilai antara nilai publik dan nilai ekonomi/bisnis. Tanggung jawab pemerintah untuk mengelola berbagai kepentingan khusunya kepentingan publik (publicness) melalui berbagai macam regulasi sulit terpenuhi dan sering dianggap tidak sejalan menurut pandangan kelompok-kelompok perekonomian. Sehingga menimbulkan conflict of interest antara kepentingan publik (direpresentasikan melalui kepentingan regulasi) versus kepentingan ekonomi yang berpotensi mereduksi publicness itu sendiri.

Berdasarkan hal tersebut, grand question yang patut dilontarkan atas kemelut isu atau permasalahan yang terjadi khususnya menyangkut publicness yaitu bagaimana pengelolaan publicness dilakukan ketika adanya hegemoni perekonomian atau kepentingan pasar dominan? Kemudian pertanyaan lanjutan yang wajib dikemukakan yaitu bagaimana pemerintah mempertahankan publicness dan implikasinya terhadap nilai publicness itu sendiri? Serta bagaimana kontrol pemerintah dalam mempertahankan publicness? Pertanyaan-pertanyaan tersebut tentunya menantang untuk dijawab pada fakta atau kenyataan yang terjadi di lapangan.

Konsep publicness erat kaitannya dengan ranah privat. Publicness muncul guna melindungi masyarakat dari serangan ruang privat warga lainnya (Pesch, 2005: 48). Publicness seringkali digunakan untuk 
membandingkan organisasi publik dan swasta dalam hal pelayanan dan pengelolaan barang ataupun jasa. Adanya perubahan ataupun reduksi peran pada suatu organisasi baik publik ataupun privat, harus diikuti dengan pengukuran publicness (Margono et., al., 2014: 14). Terkait dengan pengukuran publicness, Haque (2001: 66) menjelaskan 5 (lima) kriteria spesifik ukuran publicness dalam public service, diantaranya:

1. Bidang administrasi publik, terdapat perbedaan antara organisasi publik dan privat (swasta) dalam menentukan kriteria publicness. Perbedaan tersebut dalam hal norma-norma pelayanan seperti keberpihakan dan keterbukaan, prinsip kesetaraan, seifat monopolistik serta dampak sosial yang lebih luas dan berjangka panjang untuk masyarakat;

2. Publicness tergantung pada banyaknya masyarakat yang terlayani. Semakin besar jumlah atau cakupan kepemilikan publik, maka semakin tinggi tingkat publicness);

3. Tingkatan publicness ditentukan berdasarkan cakupan dampak sosialnya. Dengan kata lain semakin tinggi tingkat publicness, maka semakin memiliki dampak yang positif dengan jangkauan atau cakupan sosial yang luas;

4. Standarisasi publicness secara umum yaitu sejauh mana dapat dipertanggung jawabkan;

5. Ukuran sentral publicness yaitu trust masyarakat terhadap kredibilitas, kepemimpinan, dan kemampuan respon pelayanan untuk melayanai masyarakat.

Selain 5 (lima) kriteria tersebut, kualitas publicness dapat ditentukan melalui 3 (tiga) faktor dasar : "the accessibility to spaces or places, activites, information and resources; the public-private nature of agencies in control; and the status of the people who will be better or worse off for whatever is in question" (Benn dan Gaus, 1983: 3).

Dari pernyataan tersebut, ketiga faktor tersebut dapat disimpulkan ke dalam 3 (tiga) kriteria, yaitu berupa akses (fisik, aktifitas dan diskusi, informasi, dan sumberdaya), aktor (agensi), dan kepentingan. Kemudian untuk menilai baik atau buruknya publicness, perlu dilakukan pengukuran tingkatan derajat publicness (extent of publicnes) yang bergantung pada 3 (tiga) indikasi, yaitu: (1) tingkatan yang mana semua dimensi akses terpenuhi; (2) tingkatan yang mana kontrol terhadap ruang atau tempat publik dilakukan oleh aktor tunggal yakni pemerintah (publik) dan digunakan oleh masyarakat secara umum; (3) tingkatan yang mana pelayanan berorientasi pada kepentingan publik (Akka, 2005: 76). Mendasar pada tiga faktor/kriteria dan tiga indikasi publicness diatas, publicness dikatakan terkelola dengan baik bila ketiga baik faktor/kriteria dan indikasi-indikasinya telah terpenuhi atau sesuai. Begitu juga sebaliknya, apabila ketiga faktor/kriteria dan indikasi penilaian tersebut tidak terpenuhi, maka dapat dikatakan publicness tidak terkelola secara baik atau dengan kata lain publicness berkualitas buruk.

Dalam mencermati publicness, organisasi publik perlu mempertimbangkan perspektif ekonomi dan politik secara kolaboratif (Margono, et., al., 2014: 14; Zald dan Wamsley, 1973 dalam Moulton, 2009). Menurut pandangan politik, negara perlu mengontrol public interest dan 
public goods. Dan di sisi lain melalui pandangan ekonomi, negara perlu mengontrol pasar dan mengelola public goods melalui kenyataan adanya market failure (Ibid). Oleh sebab itu, pengelolaan dan kontrol public goods yang dilakukan pemerintah atau negara guna mengedepankan publicness tak bisa dilepaskan dari public interest dan public value. Orientasi publik pada pencapaian publicness tidak hanya sekedar pemenuhan bentuk organisasi dalam mengelola barang/tempat publik yang menjadi domain administratif belaka, tapi lebih dari itu pencapaian publicness juga menjadi domain ekonomi dan politik pada organisasi yang melakukannya serta realisasi komitmen untuk dapat mempertahankan eksistensi publiknya (Margono, et., al., 2014: 15, 16).

Selanjutnya mengenai negosiasi, negosiasi merupakan proses penciptaan keputusan dengan mempertimbangkan objek perselisihan dan perilaku untuk mendamaikan atau mempertemukan kepentingan yang bertentangan (Ma, 2008: 774-790). Negosiasi berarti melakukan perundingan antar berbagai pihak guna mecapai sebuah persetujuan, mengatur/menentukan melalui diskusi dan persetujuan secara mufakat (Berlin, 2008: 13-15). Capaian dari adanya negosiasi yakni berupa persetujuan terbaik yang dapat diterima oleh smua pihak.

Terdapat 4 (empat) unsur dalam proses negosiasi, diantaranya : (1) adanya perselisihan atau pertentangan, (2) adanya tahap saling ketergantungan antar pihak, (3) adanya situasi yang kondusif untuk berinteraksi, (4) adanya kemungkinan untuk mencapai kesepakatan (Guntur,
2010). Kemudian dalam prosesnya, negosiasi terdiri dari 4 (empat) kunci subproses (Fazzi dan Cindi, 2003), yakni:

1. Perundingan distributif, cara setiap pihak menyelesaikan pertentangan ketika kepentingannya berada dalam konflik;

2. Perundingan integratif, proses mencapai keuntungan bersama;

3. Perundingan intra-organizational, individu-individu yang diwakilkan oleh kelompok;

4. Penyusunan sikap, bagaimana setiap pihak saling merasakan atau bertoleransi satu sama lain.

Melalui teori negosiasi, akan diurai proses penyelesaian konflik antara pemerintah dan kelompok ekonomi yang digambarkan dalam konteks konflik kepentingan antara regulasi dan ekonomi. Kepentingan publik yang direpresentasikan melalui regulasi bersinggungan dengan kepentingan ekonomi/bisnis dalam tubuh kelompok perekonomian di satu wilayah dan menajamkan konflik vertikal. Kemudian akan dianalisis bagaimana implikasi dari negosiasi tersebut terhadap keberadaan nilai publicness, apakah publicness terkelola dengan baik atau malah tereduksi.

\section{B. Metode Penelitian}

Metode penelitian yang digunakan yaitu dengan penggunaan metode penelitian kualitatif. Sedangkan pendekatan yang digunakan yakni pendekatan studi kasus dengan tipe studi kasus instrumental tunggal yang berfokus pada persoalan atau isu tertentu, yakni publicness. Kemudian lokasi penelitian berada di kawasan Malioboro-Ahmad Yani Kota Yogyakarta, Provinsi Daerah Istimewa Yogyakarta. 
Sumber dan jenis data berupa data primer dan data sekunder. Subjek penelitian (informan) ditentukan dengan teknik purposive sampling, diantaranya: pimpinan UPT Malioboro, wakil pimpinan UPT Malioboro, ketua paguyuban parkir Malioboro, ketua paguyuban Handayani, ketua paguyuban Tri Dharma, dan ketua paguyuban Pemalni. Kemudian Teknik pengumpulan data berupa observasi, wawancara dan dokumentasi. Selanjutnya teknik analisa data mengikuti model interaktif Miles dan Huberman dengan tahapan yang terdiri dari pengumpulan data, reduksi data, penyajian data dan penarikan kesimpulan.

\section{Hasil dan Pembahasan}

1. Pengelolaan Publicness dibalik Sejarah Perkembangan Kelompok Perkonomian Kawasan MalioboroAhmad Yani

Kawasan Malioboro-Ahmad Yani merupakan tempat yang begitu kompleks dengan berbagai macam aktifitas dan kepentingan baik pemerintahan, perekonomian, kepublikan dan kepariwisataan. Kompleksitas tersebut mengharuskan pemerintah untuk melakukan penataan dan pengelolaan secara menyeluruh melalui UPT Malioboro. Sebagai unit khusus secara legal formal dalam mengelola kawasan Malioboro-Ahmad Yani, tupoksi UPT Malioboro sendiri tidak hanya sebatas melakukan pengelolaan kawasan Malioboro-Ahmad Yani, namun juga melakukan penataan aktifitas perekonomian dan pemberdayaan terhadap kelompok perekonomian di kawasan tersebut. Hal ini dilakukan guna menciptakan ketertiban dikalangan kelompok ekonomi dalam menggunakan ruang-ruang dan tempat umum sebagai lahan perdagangan agar kepentingan publik juga dapat terkomodasikan.

Sebagai organisasi pemberi pelayanan kepada masyarakat, UPT Malioboro sudah sepantasnya mengelola berbagai kepentingan masyarakat secara umum, secara khusus kepentingan publik (publicness) di kawasan MalioboroAhmad Yani karena publicness terancam oleh dominasi perekonomian. Aktifitas perekonomian di kawasan MalioboroAhmad Yani merupakan permasalahan tersendiri bagi pemerintah. Kebutuhan akan lahan perdagangan menjadi permasalahan yang selalu muncul kepermukaan. Lahan yang terbatas, sedangkan aktifitas perekonomian semakin berkembang bahkan terkukuhkan melalui pembentukan kelompok perekonomian. Pada kondisi yang demikian, pengelolaan publicness selalu berhadapan dengan kepentingan perekonomian.

Mengelola publicness dalam kasus kawasan Malioboro-Ahmad Yani yaitu mempertahankan dan memprioritaskan kepentingan publik ditengah tekanan gelombang dominasi perekonomain ketika eksistensi kelompok perekonomian kian mantap. Keberadaan nilai publicness kemudian dipertanyakan tatkala masuk dan berkembangnya kelompok-kelompok perekonomian sebagai suatu kekuatan yang solid dalam tatanan sosial, politik, ekonomi dan budaya masyarakat yang sanggup merubah sistem, orientasi serta intervensi pengelolaan kawasan Malioboro-Ahmad Yani. 
Menganalisis keberadaan nilai publicness, tidak bisa terpisahkan dari sejarah masuknya pelaku-pelaku ekonomi di kawasan Malioboro-Ahmad Yani. Nilai publicness mendapatkan tekanan dimulai pada tahun 1970-an ketika pelaku-pelaku ekonomi masuk dan menempati lahanlahan kosong di kawasan MalioboroAhmad Yani secara ilegal. Perkembangan para pelaku ekonomi terus mengalami peningkatan dan berbanding lurus dengan reduksi luas lahan untuk publik sehingga menyebabkan perubahan peruntuhan fungsi lahan. Pada kondisi yang demikian nilai publicness tertekan dan harus berhadapan dengan nilai ekonomi/bisnis yang menjadi entitas para pelaku ekonomi.

Publicness semakin terancam ketika para pelaku ekonomi berkembang dengan memantapkan diri membentuk kelompokkelompok perekonomian yang dicirikan dari kategori dagangan. Kelompok ekonomi yang terbentuk pertama kali di kawasan Maliobro-Ahmad Yani yaitu paguyuban Tri Dharma pada tahun 1982 meskipun tanpa status formal dari pemerintah. Adanya paguyuban Tri Dharma tersebut, maka semakin memantapkan posisi PKL untuk mendominasi lahan-lahan di kawasan Malioboro-Ahmad Yani sebagai lahan perdagangan. Paguyuban Tri Dharma bertransformasi menjadi kekuatan yang solid pada tataran sosial, ekonomi, politik dan budaya yang mana dapat mempengaruhi kebijakan di kawasan Malioboro-Ahmad Yani. Pengaruh tersebut ditandai dengan dikukuhkannya keberadaan paguyuban Tri Dharma secara hukum melalui SK Walikota Kota Yogyakarta No. 056/KD/1987 tentang pengaturan pedagang kakilima di Kota
Yogyakarta, termasuk PKL di kawasan Malioboro-Ahmad Yani. Peraturan tersebut merupakan peraturan pertama yang mengatur keberadaan PKL di kawasan Malioboro-Ahmad Yani sekaligus menjadi payung hukum bagi paguyuban Tri Dharma serta semakin memantapkan posisi kelompok perekonomian dalam memanfaatkan lahan di kawasan Malioboro-Ahmad Yani khususnya di jalur pedestrian yang menghadap toko.

Status formal paguyuban Tri Dharma yang telah diakui pemerintah akhirnya memicu semangat kelompok perekonomian yang lain untuk mendapatkan pengakuan yang serupa agar dapat turut bermain dalam memanfaatkan lahan kawasan MalioboroAhmad Yani sebagai lahan perdagangan. Sehingga pada tahun 1996, dilakukan revisi terhadap SK sebelumnya menjadi SK Walikota Kota Yogyakarta No. 113 tahun 1996 dengan dilegalkannya paguyuban Pemalni dalam menggunakan lahan di kawasan Malioboro-Ahmad Yani untuk aktifitas perekonomian di jalur pedestrian yang membelakangi toko.

Adanya kenyataan tersebut, semakin menegaskan bahwa pada level kritis, sikap otoritas pemerintah tampil untuk menyelesaikan permasalahan yang muncul ke permukaan dengan menjaga tensi agar tetap rendah tanpa melahirkan permasalahan baru. Pada kondisi yang demikian, sebetulnya otoritas pemerintah turut melemahkan derajat publicness karena melegalkan aktifitas kelompok perekonomian dengan menggunakan lahan-lahan di kawasan Malioboro-Ahmad Yani. Secara tidak langsung pemerintah 
menunjukkan ketidak-konsistenannya dalam melindungi publicness.

\section{Intervensi Kelompok Perkonomian dalam Mengelola Kawasan Malioboro - Ahmad Yani}

Aktor pengelola kawasan MalioboroAhmad Yani secara formal yaitu UPT Malioboro. Meskipun UPT Malioboro ditunjuk oleh Walikota sebagai aktor yang berhak mengelola kawasan MalioboroAhmad Yani, namun pada kenyataannya ada aktor lain yang turut bermain sebagai pengelola kawasan tersebut, yakni kelompok-kelompok perekonomian. Berdasarkan fakta dilapangan, wilayah cakupan yang dikelola dan dikuasai oleh kelompok perekonomian terbagi dalam tiga wilayah: lahan parkir, lahan, didepan toko dan lahan lapak makanan didepan kantor pemerintahan. Sedangkan kelompok (paguyuban) yang menjadi pengelola yaitu diantaranya: paguyuban Tri Dharma, paguyuban Pemalni, paguyuban Handayani, paguyuban Pedagang Lesehan Malioboro (PPLM) dan paguyuban parkir Malioboro.

Dari kelima paguyuban tersebut, hanya satu paguyuban yang secara resmi menjadi mitra UPT Malioboro, yakni paguyuban parkir yang termaktud dalam Perwal Yogyakarta No. 18 tahun 2009 tentang penyelenggaraan perparkiran. Sedangkan paguyuban lainnya tidak memiliki wewenang secara tertulis sebagai badan resmi yang turut mengelola kawasan Maliobiro-Ahmad Yani. Dengan begitu keturut-sertaan paguyuban sebagai aktor pengelola meskipun tanpa surat tugas, diartikan sebagai intervensi dalam mengelola kawasan Malioboro-Ahmad Yani. Intervensi yang yang dilakukan oleh kelompok-kelompok ekonomi, muncul dengan sendirinya sebagai bentuk inisiatif atas dasar melindungi kepentingannya yang berbenturan dengan kepentingan pemerintah. Pemahaman terhadap situasi dan kondisi lahan yang ditempati juga merupakan alasan pengambil-alihan pengelolaand dari tangan pemerintah.

Intervensi pengelolaan kawasan Malioboro-Ahmad Yani semakin memantapkan dominasi dan eksistensi kelompok-kelompok perekonomian dalam ranah konflik kepentingan antara publik dan ekonomi. Dalam perspektif publicness, intervensi yang terjadi menunjukkan kelemahan dan kegagalan pemerintah. Teori ekonomi politik menyebutkan pemerintah perlu mengontrol public interest dan mengontrol pasar dibalik kenyataan adanya sistem dominasi oleh pasar dalam hal ini kelompok ekonomi. Namun kepentingan publik gagal terkelola dengan baik ketika kelompok ekonomi yang terlembaga secara legal formal berhasil mengintervensi pengelolaan dari pemerintah.

\section{Pengelolaan Publicness dibalik Konflik Kepentingan antara Pemerintah dan Kelompok Ekonomi} Kawasan Malioboro-Ahmad Yani merupakan arena konflik antar lembaga dan nilai yang diembannya. Konflik vertikal antara pemerintah dan kelompok perekonomian disinyalir berakar dari isu penggunaan lahan sebagai lahan aktifitas perekonomian. Aktifitas kelompokkelompok ekonomi di kawasan MalioboroAhmad Yani berada pada titik lokasi dimana semua kepentingan setiap stakeholder melebur jadi satu. Lahan di kawasan Malioboro-Ahmad Yani menjadi 
sumberdaya yang diperebutkan oleh berbagai aktor. Kelompok perekonomian menghendaki tersedianya lahan yang strategis, pemerintah menginginkan ketersediaan lahan dan ruang sebagai tempat aktifitas publik, dan masyarakat (wisatawan) menginginkan ketersediaan lahan yang terbebas dari kepadatan aktifitas perekonomian. Sedangkan situasi di lapangan sendiri menunjukkan bahwasanya ketersediaan lahan sangat terbatas untuk mewadahi semua kepentingan yang ada. Sangatlah wajar bila terjadi konflik kepentingan dan perebutan lahan antar aktor.

Dalam ranah konflik kepentingan yang demikian, keputusan yang dikeluarkan pemerintah sering berujung pada penolakan yang dilakukan oleh kelompok perekonomian. Pemerintah dianggap tidak mampu memenuhi kepentingan kelompok perekonomian, sehingga muncul distrust kepada pemerintah akibat keputusan yang terlalu merugikan. Di satu sisi pemerintah beranggapan keberadaan kelompok perekonomian harus dikelola melalui regulasi yang diciptakan pemerintah. Di sisi lain kelompok perekonomian enggan kepentingannya dikerdilkan melalui peraturan pemerintah. Pada kondisi yang demikian pengelolaan publicness mengalami hambatan. Peran negara lantas dipertanyakan karena yang menjamin kesejahteraan penduduknya justru negara itu sendiri. Ketika terjadi ketidaksepakatan, resistensi muncul kepermukaan. Akibatnya kelompok perekonomian mengupayakan dengan caranya sendiri untuk melindungi kepentinganya baik dengan turun ke jalan maupun menghimpun kekuatan melalui pondasi relasi politik.
Konflik yang tercipta pada akhirnya dapat direda dengan langkah persuasif guna membangun kesepakatan-kesepakatan melalui pertemuan untuk berdiskusi yang mana pada dasarnya merupakan suatu bentuk negosiasi antar pihak dalam rangka mengakomodasikan masing-masing kepentingan. Kesepakatan yang telah dibangun sejak awal sampai saat ini di dominasi oleh kemenangan kelompok ekonomi, seperti kesepakatan perizinan dalam penggunaan fasilitas publik sebagai tempat perdagangan. Atas nama pemberdayaan, gerak pemerintah memiliki batasan untuk mengedepankan kepentingan publik karena kelompokkelompok perekonomian merupakan aset dalam pariwisata kawasan MalioboroAhmad Yani.

Bernegosiasi merupakan cara yang efektif pada tataran konflik kepentingan seperti ini. Intensitas konflik dapat diredam melalui komunikasi antar pihak, tercipta ruang komunikasi secara berkelanjutan dan terlembaga, dan membangun kembali trust antar pihak. Aksi negosiasi merupakan upaya dalam mempertahankan publicness dibalik konflik vertikal yang terjadi. Namun terkadang hasilnya tidak sesuai harapan bahkan menjadi sebuah ironi bagi pemerintah, dibalik keberhasilan meredam konflik, namun sarat akan kegagalan dalam menjaga eksistensi publicness seperti pengurangan jalur pedestrian akibat munculnya perizinan penggunaan fasilitas publik sebagai tempat perdagangan.

\section{Kegagalan dan Reduksi Publicness}

Lemahnya bargaining power pemerintah melahirkan dominasi pengelolaan dan penguasaan lahan di kawasan Malioboro- 
Ahmad Yani oleh kelompok perekonomian. Perubahan peruntuhan fungsi awal merefleksikan lemahnya peran pemerintah dan hasil negosiasi yang selalu memenangkan kelompok perekonomian sehingga publicness tereduksi. Reduksi publicness dilihat berdasarkan kerangka teoritik Benn dan Gaus (1983) dengan menganalisis tiga kriteria, yaitu akses, aktor dan kepentingan. Sedangkan orientasinya harus berorientasi publik.

Pada kriteria akses, publicness tereduksi. Aktor pengelola baik pemerintah ataupun kelompok ekonomi gagal memberikan akses yang utuh kepada publik, misalnya akses terhadap kenyamanan fasilitas publik. Kemudian pada kriteria aktor, publicness juga terduksi karena terdapat aktor lain melalui intervensi pengelolaan kawasan Malioboro-Ahmad Yani. Selanjutnya pada kriteria kepentingan, publicness jelas terduksi karena orientasi pengelolaan yang ditampilkan oleh kelompok perekonomian jelas tidak memiliki orientasi publik, melainkan orientasi bisnis sehingga kepentingan publik terpinggirkan. Berdasarkan ketiga kriteria tersebut, dapat ditarik kesimpulan bahwa publicness di kawasan MalioboroAhmad Yani belum bisa dikatakan berkualitas baik, akses yang terhambat, aktor pengelola bukan negara dan pelayanan yang tidak berorientasi publik sehingga mendiskreditkan publicness. Publicness tidak sepenuhnya hilang pada kawasan Malioboro-Ahmad Yani, melainkan kualitas dan derajatnya yang semakin kian menurun.

\section{Pengelolaan Publicness Kontrol Pemerintah}

Sebelum dilakukan relokasi parkir secara massal di awal bulan April tahun 2016, kontrol pemerintah terhadap kawasan Malioboro-Ahmad Yani masih lemah. Sanksi yang tidak tegas hanya berupa teguran semata ketika adanya pelanggaran berupa pelanggaran batas publik menunjukkan kelemahan kontrol pemerintah. Pemerintah melalui UPT Malioboro yang semestinya memiliki kekuatan otoritas mengatur perubahan, nyatanya tidak mampu untuk mengontrol dinamika perekonomian yang semakin mendominasi. Eksistensi publicness pada kondisi yang demikian sulit untuk dipertahankan karena ketidak-ketegasan pemerintah itu sendiri.

Pola dinamika publicness menuju posisi yang terpinggirkan dalam konteks kontrol oleh pemerintah dapat terbaca ketika kelompok ekonomi masuk ke kawasan Malioboro-Ahmad Yani, publicness seketika mengalami ancaman. Kemudian publicness melemah ketika kelompok ekonomi berhasil mendapatkan perizinan dalam menggunakan fasilitas publik (jalur pedestrian). Aksi dominasi dan intervensi terhadap pengelolaan serta pemindah tanganan kepemilikan lahan melalui praktek jual beli lahan semakin mengukuhkan penguasaan kelompok perekonomian terhadap kawasan Malioboro-Ahmad Yani. Pola tersebut menggambarkan bagaimana publicness berhasil direduksi ketika berhadapan dengan kelompok ekonomi dan peran pemerintah dalam hal kontrol terhadap kawasan Malioboro-Ahmad Yani melemah sehingga dapat dikatakan nilai publicness 
telah gagal dipertahankan sebelum adanya kebijakan relokasi parkir kendaraan.

Setelah dilakukan relokasi parkir kendaraan, terjadi peningkatan kualitas publicness ke arah yang lebih positif. Nilai-nilai publicness yang sebelumnya tersingkirkan berhasil dikembalikan pemerintah melalui relokasi parkir kendaraaan ke tempat khusus parkir (TKP) Abu Bakar Ali. Pemerintah berhasil menguatkan kontrolnya terhadap kawasan MalioboroAhmad Yani. Dinamika publicness yang terjadi di kawasan Malioboro-Ahmad Yani melalui kontrol pemerintah semakin mengalami peningkatan ke arah positif karena terbukanya akses fisik terhadap fasilitas publik (jalur pedestrian sebelah timur) yang sebelumnya ditempati dan dikuasai oleh kelompok parkir. Kemudian kontrol mutlak berada di tangan pemerintah (UPT Malioboro), serta kepentingan yang sebelumnya lebih di dominasi oleh kepentingan ekonomi, berbalik di dominasi oleh kepentingan publik

\section{Kesimpulan}

Secara umum hasil dalam penelitian ini menemukan bahwa pengelolaan publicness mengalami dinamika pasang surut selama proses perkembangan kawasan MalioboroAhmad Yani sejak masuknya kelompok ekonomi. Lahirnya kelompok perekonomian di kawasan MalioboroAhmad Yani menjadi titik dimana nilai publicness dipertaruhkan dalam ranah konflik antara aktor formal: pemerintah dan informal: kelompok-kelompok ekonomi. Ketika klaim lahan melahirkan konflik, maka timbul gerakan tersendiri melalui jalur institusional ataupun noninstitusional dalam upaya melindungi kepentingan masing-masing pihak. Dan ketika hal tersebut terjadi, maka entitas yang berbeda dari setiap aktor saling berbenturan sehingga berpengaruh negatif bagi nilai publicness.

Sehubungan dengan hal tersebut, saran yang dapat ditawarkan diantaranya: perlunya memperluas cakupan pengelolaan dan pengawasan terhadap aktifitas perekonomian, perlu memprediksi perkembangan kelompok perekonomian agar dapat diantisipasi dikemudian hari, perlu bertindak tegas dengan menerapkan sanksi terhadap berbagai pelanggaran, dan perlu meningkatkan sosialisasi yang lebih intens terkait batasan maupun cara pengelolaan yang berorientasi publik.

\section{Daftar Pustaka}

Akka, Z. Muge. 2005. Questioning The Publicness of Public Spaces in Postindustrial Cities. Tradional Dwelling and Settlements Review. Vol. XVI, No. 11

Benn, Stanley I. dan G. F. Gaus. 1983. The Public and The Private: Concepts and Action. Croom Helm: London

Berlin, Jonathan W. 2008. The Fundamental of Negotiation, Vol. 58, No. 1, p13-15

Cahyadi, A., A.Z. Fadlur R., Nailatalmuna N.A., Nuku N.S., R. Rustiana, T.R. Mallany dan Y. Puspitasari. 2011. Politik Perparkiran di Malioboro: Dominasi Aktor Informal dalam Pengelolaan Parkir. Research Centre for Politics and Government (PolGov) UGM: Yogyakarta.

Fazzi dan Cindi. 2003. Book Review: Negotiation Theory and Application: The Next Generation, Vol. 58, No. 3 
Haque, M. Shamsul. 2001. The

Deminishing Publicness of Public Service Under The Current Mode of Governance, Vol. 61, No. 1

Ma, Zhenzhing. 2008. Personality and Negotiaion Revisited: Toward a Cognitive Model of Dyadic Negotiation, Vol. 31, No. 10

Margono, Subando A., Suharyanto, I M. Krisnajaya, AG. Subarsono dan B. Sunaryo. 2014. Fenomena Pengelolaan Publicness Melalui Organisasi Non-publik. GAVA MEDIA: Yogyakarta

Moulton, Stephanie. 2009. Putting Together The Publicness Puzzle: A Framework For Realized Publicness Pesch, Udo. 2005. The Predicaments of Publicness, Eburon Academics Publishers: Netherland

Putri, K. Indah. 2015. Penerapan Pasal 3 Peraturan Presiden Nomor 125 Tahun 2012 tentang Koordinasi Penataan dan Pemberdayaan Pedagang Kaki Lima, Vol. 22, No. 1. 